\title{
NEPHROPROTECTIVE ACTIVITY OF ETHANOL EXTRACT ROOT OF COGON GRASS (IMPERATA CYLINDRICA L. (BEAUV.)) ON CREATININE, UREA LEVELS, AND HEMATOLOGY PROFILE AGAINST GENTAMYCIN-INDUCED RENAL TOXICITY IN RATS
}

\author{
ANINDITHA RACHMAH RAMADHIANI, URIP HARAHAP*, AMINAH DALMUNTHE
}

Department of Pharmacology, Faculty of Pharmacy, Universitas Sumatera Utara, Medan, Indonesia. Email: urip.hrp@gmail.com Received: 07 March 2018, Revised and Accepted: 25 March 2018

\section{ABSTRACT}

Objective: This study aimed to evaluate the effect of ethanol extract root of cogon grass on parameter creatinine, urea levels, and hematology profile in rats induced by gentamicin.

Methods: Thirty rats were divided into 6 groups of normal group (without treatment), groups of treatment only fed and watered, given carboxymethylcellulose (CMC) $0.5 \%$, ethanol extract of the roots of cogon grass with each dose of 100, 200, and $400 \mathrm{mg} / \mathrm{kg}$ BW. Each group was given the test preparation orally for 8 days. After $1 \mathrm{~h}, 5$ groups were induced by gentamicin at a dose $100 \mathrm{mg} / \mathrm{kg}$ bw intraperitoneally during 8 days. On the $9^{\text {th }}$ day, blood samples were collected for serum creatinine, urea levels, and hematological parameters; hemoglobin (Hb), red blood cell, and packed cell volume.

Results: Ethanol extract root of cogon grass doses of $100 \mathrm{mg} / \mathrm{kg} \mathrm{bw}, 200 \mathrm{mg} / \mathrm{kg}$ bw, and $400 \mathrm{mg} / \mathrm{kg}$ BW significantly decreased serum creatinine and urea levels, significantly increased hematological parameters as compared to negative control group of CMC $0.5 \%$ and negative control group not given CMC 0.5\% ( $<0.05)$. Ethanol extract root of cogon grass at a dose of $400 \mathrm{mg} / \mathrm{kg}$ bw showed there were not differences of creatinine, urea levels, and profile of hematology compared with normal group ( $\mathrm{p}>0.05)$.

Conclusion: The ethanol extract root of cogon grass at a dose of $400 \mathrm{mg} / \mathrm{kg}$ bw was effective to ameliorate creatinine, urea levels, and hematological parameters.

Keywords: Gentamicin, Cogon grass, Imperata cylindrica L. (Beauv.), Creatinine, Urea, Profile of hematology.

(c) 2018 The Authors. Published by Innovare Academic Sciences Pvt Ltd. This is an open access article under the CC BY license (http://creativecommons. org/licenses/by/4. 0/) DOI: http://dx.doi.org/10.22159/ajpcr.2018.v11s1.26578

\section{INTRODUCTION}

Gentamicin is an aminoglycoside antibiotic widely used to treat infections caused by Gram-negative bacteria. However, based on the study, it was found that the duration and frequency of irrational use are still common [1]. Gentamicin-induced acute nephrotoxicity is characterized by decreased urine excretion, ammonium excretion, glomerulus filtration rate, tubular proteinuria, electrolyte disturbance, and elevated levels of urea, and creatinine plasma [2].

The mechanism of gentamicin induces acute renal failure to occur in several stages, starting from accumulated gentamicin in proximal tubular cells and then binding to the phospholipid membrane leading to phospholipidosis. Phospholipidosis will increase the formation of reactive oxygen species (ROS) causing apoptosis [3]. ROS caused renal tubular lesions and necrosis so decreased the production of erythropoietin (EPO) hormones in renal proximal tubular cells that act as physiological regulators of erythropoiesis thus, giving gentamicin will cause anemia [4].

Roots of cogon grass have been used in the empiric for acute kidney disorders, by boiling roots of cogon grass as much as $60-120 \mathrm{~g}$ with three glasses of water, taken 3 times a day. Based on study roots of cogon grass contained secondary metabolites such as alkaloids, flavonoids, glycosides, saponins, steroids, and tannins [5]. Water extract roots of cogon grass have been shown a nephroprotective effect on gentamicin-induced rats [6]. The nephroprotective effect is thought by flavonoid compounds belonging to the flavonol group contained that has antioxidant activity by free radical scavenger [7].

\section{METHODS}

\section{Plant material}

The plant material is made up of the root of Imperata cylindrica L. (Beauv) was collected in Medan in April 2017. The sample of the plant was identified at LIPI Bogor.

\section{Preparation of extracts}

The root of I. cylindrica L. (Beauv) was washed and dried at $40^{\circ} \mathrm{C}$ temperature for 2 weeks. The dried plant material was made to a coarse powder and stocked at a later use. The extract was prepared by percolation using ethanol $96 \%$.

\section{Phytochemical screening}

The different groups of compounds (steroids, flavonoids, alkaloids, tannins, saponins, and glycosides) were screened in the ethanol extracts of cogon grass according to the standard procedures.

\section{Experimental animals}

Thirty male rats weighing \pm 170 g were used for this study. The animals were housed in plastical cages and acclimatized; they were maintained under standard conditions. Rats were divided into six groups comprising of five animals each.

Group I: Normal group (without treatment).

Group II: Administered gentamicin (100 mg/kg/bw) intraperitoneally. Group III: Given carboxymethylcellulose (CMC) $0.5 \%$, after $1 \mathrm{~h}$ were induced by gentamicin at a dose of $100 \mathrm{mg} / \mathrm{kg}$ bw intraperitoneally.

Group IV: Received ethanol extract of the roots of cogon grass at a dose of $100 \mathrm{mg} / \mathrm{kg} \mathrm{bw}$, after $1 \mathrm{~h}$ were induced by gentamicin at a dose of $100 \mathrm{mg} / \mathrm{kg}$ bw intraperitoneally.

Group V: Received ethanol extract of the roots of cogon grass at a dose of $200 \mathrm{mg} / \mathrm{kg} \mathrm{bw}$, after $1 \mathrm{~h}$ were induced by gentamicin at a dose of $100 \mathrm{mg} / \mathrm{kg}$ bw intraperitoneally.

Group VI: Received ethanol extract of the roots of cogon grass at a dose of $400 \mathrm{mg} / \mathrm{kg} \mathrm{bw}$, after $1 \mathrm{~h}$ were induced by gentamicin at a dose of $100 \mathrm{mg} / \mathrm{kg}$ bw intraperitoneally.

Each group was given administered for 8 days. On the $9^{\text {th }}$ day, rats were sacrificed for blood collection for serum creatinine, urea levels, and 
hematological parameters (hemoglobin [Hb], red blood cell [RBC], and packed cell volume [PCV]) analysis.

\section{Biochemical and hematological analysis}

A period of $24 \mathrm{~h}$ after the last treatment, the animals were cervical dislocation; blood was collected by venous cava inferior. Serum creatinine and urea-nitrogen concentrations were measured by AutoAnalyzer (Cobas Integra). The hematological parameters $(\mathrm{Hb}$, $\mathrm{RBC}$, and PCV) were determined using an automatic blood cell counter (Sysmex KX 21).

\section{Statistical analysis}

The data were expressed as mean \pm standard error mean. SPSS 23.0 software was used for the analysis of the results obtained. Comparisons of the measured parameters among different groups were made using one-way ANOVA followed by least significant difference test. The significance level was accepted at $\mathrm{p}<0.05$.

\section{RESULTS AND DISCUSSION}

\section{Phytochemical screening}

Phytochemical analysis of ethanolic extract roots of cogon grass revealed the presence of large chemical groups that were: Alkaloids, steroids, terpenes, tannins, flavonoids, saponins, and glycosides (Table 1).

\section{Biochemical and hematological analysis}

Intraperitoneal injection of gentamicin at a dose of $100 \mathrm{mg} / \mathrm{kg}$ bw/day for 8 days to rats caused nephrotoxicity manifested by the concentration of serum urea and creatinine negative control group (Group V and VI) were significantly increased as compared to the normal Group (IV). Treatment with cogon grass extract (I-III) showed a significant decrease $(p<0.05)$ in the concentration of serum creatinine and urea as compared to negative group (Group V and VI). There was no statistically significant difference ( $p>0.05)$ between negative group (Group V and VI). Ethanol extract roots of cogon grass dose at a dose of $400 \mathrm{mg} / \mathrm{kg}$ BW showed there were no differences of creatinine, and urea levels compared with normal group ( $\mathrm{p}>0.05)$.

Hematological parameters showed significantly decreased $(\mathrm{p}<0.05)$ in the negative control group compared to the normal group. Treatment with cogon grass extract doses of 200 and $400 \mathrm{mg} / \mathrm{kg}$ bw showed the level of RBC, $\mathrm{Hb}$, and PCV were not statistically significant difference compared to normal group $(\mathrm{p}>0.05)$. Ethanolic extract treatment of cogon grass at a dose of $100 \mathrm{mg} / \mathrm{kg}$ bw was not significantly different

Table 1: Qualitative analysis roots of cogon grass

\begin{tabular}{llll}
\hline No. & Phytochemical & Simplicia & Extract \\
\hline 1. & Flavonoids & + & + \\
2. & Alkaloids & + & + \\
3. & Saponins & + & + \\
4. & Tannins & + & + \\
5. & glycosides & + & + \\
6. & Steroids/terpenes & + & + \\
\hline
\end{tabular}

compared to the negative group in RBC parameters (Table 2). Based on this study showed the effect depends on dose; increasing the dose can increase the effect.

\section{DISCUSSION}

Gentamicin is an aminoglycoside antibiotic widely used to treat infections caused by Gram-negative bacteria. However, gentamicin induces acute nephrotoxicity which characterized by increased serum creatinine, urea, anemia, electrolyte disturbance, and tubular necrosis, glomerular atrophy, hemorrhage and hyalin cast in renal, decreased creatinine clearance, urine volume, glutathione s-transferase (GSH), and catalase $[8,9]$. The cytotoxicity of gentamicin occurs in cells where drug accumulates in the kidney and proximal tubules. Gentamicin will form a complex with megalin and cubilin. This complex is known to transport gentamycin by endocytosis and accumulates mostly in lysosomes, the Golgi and endoplasmic reticulum. Gentamicin binds to the phospholipid membrane, alters onset and metabolism resulting phospholipidosis [3].

Gentamicin affects the mitochondria through direct and indirect pathways. The direct mechanism is to activate the intrinsic pathway of apoptosis, affect the respiratory tract, inhibit the production of adenosine triphosphate, and produce oxidative stress by increasing superoxide anions and hydroxyl radicals that contribute to cell death. The indirect mechanism is by inhibiting proteasomal degradation thus increasing the active protease enzyme, cathepsins, that induce cell death. In the endoplasmic reticulum, gentamicin inhibits protein synthesis, interfering with translation resulting in a stress of the endoplasmic reticulum. If stimulation is done continuously, then apoptosis will be activated, and there will be cell death [3].

Creatinine is the end product of muscle, creatine, produced at a constant level [10]. In the formation of creatinine there is no mechanism of reuptake by the body, so most creatinine is excreted through the renals. In the event of renal dysfunction, the ability of creatinine filtration will decrease, and serum creatinine will increase [11]. Urea is the end product of protein catabolism and amino acids produced by the liver and are distributed through intracellular and extracellular fluids into the blood, filtered by the glomerulus [12]. Urea examination is helpful in establishing the diagnosis of acute glomerular renal failure [12]. However, urea measurement is a poor indicator because it is largely influenced by food, so other parameters such as creatinine are needed to measure glomerular kidney function [12].

Gentamicin-induced cell death causes lesions and necrosis of the renal tubular, which reduces the production of EPO hormones. Gentamicininduced renal histopathology causes lesions and necrosis of the renal tubular producing EPO, decreases the amount of EPO. The shortening of erythrocyte lifetime is also a contributing factor to anemia, which is related to high levels of urea in the blood that are toxic to $\mathrm{Hb}[4]$. Decreasing values of RBC, $\mathrm{Hb}$, and PCV are characteristic of anemia caused by gentamicin [13].

Based on this study, extract roots of cogon grass can reduce renal damage caused by gentamicin, the results of phytochemical studies of roots of cogon

Table 2: Effect of ethanol extract root $\mathrm{f}$ cogon grass (I. Cylindrica L. (Beauv.)) on creatinine, urea levels, and profile of hematology in rats induced by gentamicin

\begin{tabular}{|c|c|c|c|c|c|}
\hline Groups & $\begin{array}{l}\text { Creatinine } \\
(\mathrm{mg} / \mathrm{dL})\end{array}$ & $\begin{array}{l}\text { Urea } \\
(\mathrm{mg} / \mathrm{dL})\end{array}$ & $\begin{array}{l}\text { RBC } \\
\left(10^{6} / \mathrm{uL}\right)\end{array}$ & $\begin{array}{l}\text { Hb } \\
(g / d L)\end{array}$ & PCV (\%) \\
\hline I (Ethanolic extract root of cogon grass 100 mg/kg bw) & $1.12 \pm 0.14^{\mathrm{a}, \mathrm{b}, \mathrm{c}}$ & $78.8 \pm 5.89^{\mathrm{a}, \mathrm{b}, \mathrm{c}}$ & $7.858 \pm 0.59^{\mathrm{a}, \mathrm{b}, \mathrm{c}}$ & $13.66 \pm 1.30^{\mathrm{b}, \mathrm{c}}$ & $43.42 \pm 4.85^{\mathrm{b}, \mathrm{c}}$ \\
\hline II (Ethanolic extract root of cogon grass $200 \mathrm{mg} / \mathrm{kg}$ bw) & $0.728 \pm 0.12^{\mathrm{a}, \mathrm{b}, \mathrm{c}}$ & $62.8 \pm 6.98^{\mathrm{a}, \mathrm{b}, \mathrm{c}}$ & $8.8 \pm 0.80^{\mathrm{b}, \mathrm{c}}$ & $14.8 \pm 1.31^{\mathrm{b}, \mathrm{c}}$ & $46.24 \pm 4.22^{\mathrm{b}, \mathrm{c}}$ \\
\hline III (Ethanolic extract root of cogon grass $400 \mathrm{mg} / \mathrm{kg} \mathrm{bw}$ ) & $0.564 \pm 0.11^{\mathrm{b}, \mathrm{c}}$ & $47.6 \pm 8.20^{\mathrm{b}, \mathrm{c}}$ & $9.28 \pm 0.45^{\mathrm{b}, \mathrm{c}}$ & $15.9 \pm 0,63^{\mathrm{b}, \mathrm{c}}$ & $49.14 \pm 2.59^{\mathrm{b}, \mathrm{c}}$ \\
\hline IV (Normal group) & $0.384 \pm 0.12^{\mathrm{b}, \mathrm{c}}$ & $41.6 \pm 7.13^{\mathrm{b}, \mathrm{c}}$ & $8.738 \pm 0.52^{\mathrm{b}, \mathrm{c}}$ & $14.84 \pm 0.99^{\mathrm{b}, \mathrm{c}}$ & $48.1 \pm 1.39 \mathrm{~b}, \mathrm{c}$ \\
\hline V (Negative control group received CMC 0.5\%) & $1.684 \pm 0.24^{\mathrm{a}}$ & $118.2 \pm 12.46^{\mathrm{a}}$ & $6.64 \pm 0.38^{\mathrm{a}}$ & $11.08 \pm 0.93^{\mathrm{a}}$ & $36.36 \pm 3.49^{\mathrm{a}}$ \\
\hline VI (Negative control group did not receive CMC $0.5 \%$ ) & $1.674 \pm 0.14^{\mathrm{a}}$ & $112 \pm 12.61^{\mathrm{a}}$ & $6.756 \pm 0.28^{\mathrm{a}}$ & $11.5 \pm 0.79^{a}$ & $37.88 \pm 3.97^{\mathrm{a}}$ \\
\hline
\end{tabular}

Data were represented as mean \pm standard error. ${ }^{\mathrm{a}}$ means significantly different compared with normal group ( $\left.\mathrm{p}<0.05\right)$, ${ }^{\mathrm{b}}$ means significantly different compared with control negative group received CMC $0.5 \%(\mathrm{p}<0.05)$, ${ }^{\mathrm{c}}$ means significantly different compared with control negative group did not received CMC $0.5 \%$ ( $<<0.05$ ).

I. Cylindrica: Imperata Cylindrica. CMC: Carboxymethylcellulose, RBC: Red blood cell, Hb: Hemoglobin, PCV: Packed cell volume 
grass containing flavonols thought to work by increasing the antioxidant activity of GSH, and increase GSH synthesis, and free radical scavenger by donating $\mathrm{H}$ atoms to free radicals resulting non-reactive free radical compounds and cellular damage by gentamicin would be reduced [6]. This is consistent with the Poblete study which states that water extract of root of cogon grass (I. cylindrica L. (Beauv)) has been shown to have a nephroprotective effect on gentamicin-induced rats. However, this herbal medicines used by people with renal insufficiency should regularly monitor kidney function of such people, together with their electrolytes [14].

\section{CONCLUSION}

The results of this study demonstrated the significant nephroprotective activity of root of cogon grass against gentamycin-induced renal toxicity. The ethanol extract root of cogon grass at a dose of $400 \mathrm{mg} / \mathrm{kg} \mathrm{BW}$ was effective to ameliorate creatinine, urea levels, and hematological parameters.

\section{ACKNOWLEDGMENT}

The authors are grateful to Faculty of Pharmacy, University of Sumatera Utara, for providing technical facilities.

\section{AUTHORS' CONTRIBUTIONS}

ARR conceived and designed the experiments, and performed the experiments; $\mathrm{UH}$ and $\mathrm{AD}$ contributed interpretation of data, drafting and revising the manuscript for intellectual content. All authors reviewed and approved the contents of the manuscript.

\section{CONFLICTS OF INTEREST}

There are no conflicts of interest.

\section{REFERENCES}

1. Gelaw BK, Tegegne GT, Defersha AD, Legese A. Retrospective drug use evaluation of gentamycin use in ambo hospital, oromia region state,
West Showa, Ethiopia. Indian J Pharm Pract 2014;7:20-1.

2. Chatterjee P, Aniruddha M, Subhangkar N. Protective effects of the aqueous leaf extract of Aloe barbadensis on gentamicin and cisplatin-induced nephrotoxic rats. Elsevier. Asian Pac J Trop Biomed 2012;5:1754-63.

3. Novoa JM, Quiros Y, Vicente L, Morales AI, Hernandez FJ. New insights into the mechanism of aminoglycoside nephrotoxicity: An intergrative point of view. Int Soc Nephrol $2010 ; 1-4$

4. Naeshiro I, Ishimura Y, Chatani F, Sato S. Possible mechanism for the anaemia induced by gentamicin in rats. Original Article. Comp Haematol Int 1997;7:220-5.

5. Parvathy NG, Padma R, Renjith V, Rahate KP, dan Saranya TS. Phytochemical screening and anthelmintic activity of methanolic extract of Imperata cylindrica. Int J Pharm Pharm Sci 2011;4:233-4.

6. Poblete J. Nephroprotective Effects of Cogon (Imperata cylindrica) Root Aqueous Extract on Sprague-Dawley Rats with GentamicinInduced Acute Kidney Injury. Phillippines: Research and Innovation In Health For Disaster and Emergency Management 2014. p. 110-5.

7. Dahal A, Sirisha M. Flavonoids in kidney protection. review article. World J Pharm Pharm Sci 2015;4:362-5.

8. Gilbert DN, Wood CA, Kohlhepp SJ, Kohnen PW, Houghton DC, Finkbeiner $\mathrm{HC}$, et al. Polyaspartic acid prevents experimental aminoglycoside nephrotoxicity. J Infect Dis 1989;159:945-53.

9. Geetha K, Ramarao N, Sindhu B, Rao VU. Nephroprotective, nephrocurative activity of Mimosa pudica root against gentamicin induced nephrotoxicity. Int J Pharm Pharm Sci 2015;7:173-7.

10. Howard TE. Clinical Chemistry. New York: John Wiley and Sons; 1989. p. 4, 58.

11. Alfonso AA, Mongan AE, Memah MF. Serum creatinin level description on $5^{\text {th }}$ stage non dialysis Kidney Disease's patients. J e-Biomedik 2016;4:178-83.

12. Gowda S, Desai PB, Kulkarni SS, Hull VV, Math AA, Vernekar SN, et al. Markers of renal function tests. N Am J Med Sci 2010;2:170-3.

13. Badwi SM, Bakhiet AO, Gadir EH. Haemato-biochemical effect of aqueous extract of Kanaya senegalensis stem bark on gentamicininduced nephrotoxicity in wistar rats. J Biol Sci 2012;12:1-4.

14. Tangkiatkumjai M. existing evidence for safe use of herbal medicines in chronic kiney disease. review article. Int J Pharm Pharm Sci 2015;7:30- 4 . 